\title{
EMPACT OF RICE STRAW, FYM AND N FERTILIZER RATES ON WHEAT YIELD AND SOIL FERTILITY
}

El-Arqan, M. Y.*; Kh. H. El-Hamdi*; H.G. ABU El-Fotoh ${ }^{\star \star}$ and A. A. El-Wehedy*

* Soil Dept., Faculty of Agriculture, Mansoura University, Egypt.

** Soil, Water and Environment Res.Inst., Agic. Res. Center, Giza, Egypt.

\begin{abstract}
To evaluate the effect of rice straw, farmyard manure and $\mathrm{N}$ fertilizer rates on vegetative growth, yield components and chemical composition of wheat crop (Triticum aestivum L.) grown on an alluvial soil and then study the effect of aforementioned factors on soil quality during the successive season of 2005/2006 a pot experiment was performed out at Meniat El-Nasr district, Dakahlia Governorate, Egypt. Treatments were representing all combination of organic waste sources (control, rice straw (RS) and mixture of rice straw + farmyard manure (RS + FYM) were applied at the rate of $20 \mathrm{~m}^{3} \mathrm{fed}^{-1}$ and $\mathrm{N}$ fertilizer rates $(0$, half and all of recommended rate as sulfate, $20.5 \% \mathrm{~N}$ ) in presence of the used soils collected after cotton and the other collected after rice in split- split plot design with three replicates. The obtained results could be summarized as follows:

- Statistical analysis shows that the highest mean values of fresh and dry weights of wheat plant were occurred for the treatment of $20 \mathrm{~m}^{3} \mathrm{fed}^{-1}$ of RS with FYM (W2) + $37.5 \mathrm{~kg} \mathrm{~N} \mathrm{fed}^{-1}$ ( $\mathrm{N} 2$ half nitrogen dose) at the $1^{\text {st }}$ and the $2^{\text {nd }}$ soil.

- Results reveal that means of N,P and K-uptake $\left(\mathrm{g} \mathrm{pot}^{-1}\right)$ by wheat shoot of wheat were increased significantly with increasing of organic wastes rates (W0, W1 and W2) and nitrogen rates (N0, N1 and N2) at two soils under studied. The highest means of $\mathrm{N}, \mathrm{P}$ and $\mathrm{K}$-uptake at the $1^{\text {st }}$ and $2^{\text {nd }}$ soil respectively, produced from the additional of W2 (RS+FYM) at a rate of $20 \mathrm{~m}^{3} \mathrm{fed}^{-1}$ with $\mathrm{N} 2\left(37.5 \mathrm{~kg} \mathrm{~N} \mathrm{fed}^{-1}\right.$ half dose).

- Data show that the effect of rice straw (RS), rice straw RS with farmyard manure FYM and $\mathrm{N}$ fertilizer rates had a significant and an insignificant effect on grain weight $\left(\mathrm{g} \mathrm{pot}^{-1}\right)$ and weight of 100 grains $(\mathrm{g})$, respectively.

- Application of (rice + FYM) mixture $+37.5 \mathrm{~N} \mathrm{~kg} \mathrm{fed}^{-1}$ had a positive effect on residual soil-N, $\mathrm{P}$ and $\mathrm{K}\left(\mathrm{mg} \mathrm{kg} \mathrm{soil}{ }^{-1}\right)$ as well as organic matter (\%) at two alluvial soils. The highest mean values of residual soil- $\mathrm{N}, \mathrm{P}, \mathrm{K}\left(\mathrm{mg} \mathrm{kg} \mathrm{soil}^{-1}\right)$ and organic matter (\%) obtained from plots that received $37.5 \mathrm{~kg} \mathrm{n}^{-1}$ fed $^{-1}$ (half dose) plus (RS + FYM) mixture at a rate of $20 \mathrm{~m}^{3} \mathrm{fed}^{-1}$ were at the $1^{\text {st }}$ and $2^{\text {nd }}$ soil.
\end{abstract}

Keywords: Previous crop, organic wastes, $\mathrm{N}$-fertilizer, wheat crop

\section{INTRODUCTION}

Organic farming systems that are based on three practical pillars;(1) the maintenance and increase of soil fertility by the use of farmyard manure ;(2) the omission of synthetic fertilizers and synthetic pesticides; (3) the lower use of high energy consuming g feedstuff ( FlieBbach, et al., 2006).

El-Zahar et al., (2001) and Soliman et al., (2001) and Rodd et al., (2002) concluded that the addition of FYM increased grain yield of both wheat and maize.

In addition, several workers reported that the efficiency of organic wastes in the combined with $\mathrm{N}$ fertilization (Shehata et al., 2004; Saddik et al., 2004 and Wafaa et al., 2004) they indicated that the yield tended to increase 
as a result of mineral fertilizer treatment as compared to other treatments. Also, they showed that, the highest nitrogen, phosphorus and potassium percentages in leaves and stems were found in plants fertilized with NPK + chicken manure + compost at $(1 / 3+1 / 3+1 / 3)$. Therefore, the aim of the investigation was to study the interactive effect of organic wastes and nitrogen fertilizer rates on plant growth, yield and quality and nutrient contents of wheat plants as well as soil fertility of studied soil under alluvial soil conditions.

\section{MATERAILS AND METHODS}

A pot experiment was performed out at Meniat El-Nasr district, Dakahlia Governorate, Egypt to evaluate the effect of some organic residues (rice straw and farmyard manure) on vegetative growth, yield components and chemical composition of wheat crop (Triticum aestivum L.) grown on an alluvial soil during the successive season of 2005/2006 and residual effect of applied treatments on soil fertility.

Table 1: Some physical and chemical properties for the investigated soils.

\begin{tabular}{|c|c|c|c|}
\hline \multicolumn{2}{|c|}{ Soil Properties } & Soil 1 & Soil 2 \\
\hline \multirow{4}{*}{ Physical analysis } & Clay & 43.10 & 36.30 \\
\hline & Silt & 39.13 & 35.82 \\
\hline & Sand & 10.39 & 19.94 \\
\hline & Texture & Silty clay & Clay loam \\
\hline \multirow{3}{*}{ Chemical Analysis } & $\mathrm{pH}$ & 7.7 & 7.5 \\
\hline & $\mathrm{CaCO}_{3}^{-}$ & 4.9 & 6.25 \\
\hline & $E C\left(d_{S m^{-1}}\right)$ & 1.71 & 0.92 \\
\hline \multirow{3}{*}{$\begin{array}{l}\text { Avialable Nutrients } \\
\left(\mathrm{mg} \mathrm{kg} \mathrm{soil}^{-1}\right)\end{array}$} & $\mathbf{N}$ & 122.5 & 131.3 \\
\hline & $\mathbf{P}$ & 105.3 & 81.9 \\
\hline & K & 487.2 & 266.8 \\
\hline \multirow{4}{*}{$\begin{array}{l}\text { Cations } \\
(\text { meq100 g soil-1) }\end{array}$} & $\mathrm{Ca}^{+2}$ & 2.31 & 1.21 \\
\hline & $\mathrm{Mg}^{+2}$ & 2.49 & 1.38 \\
\hline & $\mathrm{Na}^{+}$ & 3.85 & 2.07 \\
\hline & $\mathrm{K}^{+}$ & 0.10 & 0.05 \\
\hline \multirow{4}{*}{ 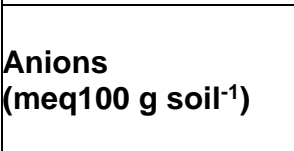 } & $\mathrm{CO}={ }_{3}$ & 0.00 & 0.00 \\
\hline & $\mathrm{HCO}_{3}^{-}$ & 2.24 & 1.96 \\
\hline & $\mathrm{Cl}^{-}$ & 6.11 & 1.22 \\
\hline & $\mathrm{SO}_{4}$ & 0.41 & 1.53 \\
\hline
\end{tabular}

The experiment was conducted out in plastic containers measuring 50 $\mathrm{cm}$ in height and $40 \mathrm{~cm}$ in diameter. Each container was filled with twenty $\mathrm{kg}$ of soil. Soil samples were collected from the surface layer $(0-30 \mathrm{~cm})$ collected after cotton cultivation to represent the $1^{\text {st }}$ soil, meanwhile the other, collected after rice cultivation to represent the $2^{\text {nd }}$ soil.

Soil is considered a clay loam in texture (alluvial soils). Some physical and chemical properties were shown in Table 1.

The experimental design was split-split plot design. Main plots were assigned to the two previous crops (collected after cotton cultivation to represent the $1^{\text {st }}$ soil, meanwhile the other, collected after rice cultivation to 
represent the $2^{\text {nd }}$ soil. While, the three organic wastes $(\mathrm{OW})$ treatments were arranged in the sub-plots and the three treatments of nitrogen $(\mathrm{N})$ were the sub-sub plots. Hence, the total number of present trial was 2 treatments (previous crops) $\times 3$ sources $(\mathrm{OW}) \times 3$ rates $(\mathrm{N})=18$ treatments. Each treatment was replicated 3 times to give a total number of 54 experimental units.

1. The first factor (2 treatments): The used soils collected as follows;

The $1^{\text {st }}$ soil collected after cotton and the $2^{\text {nd }}$ soil collected after rice.

2. The second factor (2 treatments): Three sources of organic wastes were applied at the rate of $20 \mathrm{~m}^{3}$ fed-1 as follows:

$\mathrm{W}_{0}$; Control (without addition), $\mathrm{W}_{1}$; Rice straw (RS) and $\mathrm{W}_{2}$; Mixture of rice straw + farmyard manure (RS + FYM).Some chemical analyses of rice straw and farmyard manure are shown in Table 2.

Table 2: Some chemical analyses of rice straw and (Rice straw + FYM) Mixture farmyard manure.

\begin{tabular}{|c|c|c|c|c|c|c|c|}
\hline \multirow{2}{*}{ Sources } & \multicolumn{3}{|c|}{ Total nutrients (\%) } & \multirow{2}{*}{$\begin{array}{c}\text { O.M } \\
\%\end{array}$} & \multirow{2}{*}{$\begin{array}{l}\mathbf{C} \\
\%\end{array}$} & \multirow{2}{*}{$\begin{array}{r}\mathrm{C} / \mathrm{N} \\
\text { ratio }\end{array}$} & \multirow{2}{*}{$\mathrm{pH}$} \\
\hline & $\mathbf{N}$ & $\mathbf{P}$ & K & & & & \\
\hline Rice straw & 0.54 & 0.027 & 0.55 & 9.81 & 43.0 & 79.6 & 6.5 \\
\hline (Rice straw + FYM) Mixture & 1.12 & 0.29 & 2.00 & 25.17 & 14.0 & 12.5 & 7.8 \\
\hline
\end{tabular}

3. The third factor ( $3 \mathrm{~N}$ rates): nitrogen was applied in the form of ammonium sulfate $(20.5 \% \mathrm{~N})$ and ammonium nitrate $(33.5 \% \mathrm{~N})$ at three rates 0 , half and all recommended rates $\left(75 \mathrm{~N} \mathrm{~kg} \mathrm{fed}^{-1}\right)$ of nitrogen as the following:-

$\mathrm{N}_{0}$; Control (Without addition).

$\mathrm{N}_{1}$; Half recommended rate $\left(37.5 \mathrm{~N} \mathrm{~kg} \mathrm{fed}^{-1}\right)$ equal $0.15 \mathrm{~g} \mathrm{pot}^{-1}\left(0.69 \mathrm{~g}^{-}\right.$ ammonium sulfate $+0.85 \mathrm{~g}$ of ammonium nitrate to wheat) and

$\mathrm{N}_{2}$; All recommended rate $\left(75 \mathrm{~N} \mathrm{~kg} \mathrm{fed}{ }^{-1}\right)$ equal $0.30 \mathrm{~g} \mathrm{pot}^{-1}(1.38 \mathrm{~g}$ of ammonium sulfate $+1.69 \mathrm{~g}$ of ammonium nitrate to wheat).

Organic wastes were incorporated into the soil and then soil was irrigated and left for 15 days before sowing. Three wheat seedlings were placed in the center of each pot and water was applied to the pots to maintain the soil water potential near available moisture.

Also, the nitrogenous fertilizer was added at three equal doses; the first and two doses were added after 20 days from transplanting and at the beginning of flowering and fruit set ( 45 days after transplanting). While the third dose was added after fruit setting stage (65 days after transplanting). With exception of the studied treatments, other cultural practices for wheat were used according to the recommendations of Agriculture Ministry.

\section{Agronomic characters:-}

One sample was taken after cultivation to determine the following;

\subsection{Growth attributes:-}

- Fresh weight (g/pot).

- Dry weight (g/pot).

- Chlorophyll was measured by a Minolta SPAD chlorophyll meter (Yadova, 1986).

1.2. Yield:-

At maturity, after 180 days from planting season, the grain samples were removed to measure the following attributes:- 


\section{- Weight of $\mathbf{1 0 0}$ grains (g/pot)}

Also, grains and straw were carefully taken from plants before harvesting and available soil- $\mathrm{N}, \mathrm{P}$ and $\mathrm{K}$ were estimated as mentioned by Cottenie et al., (1982).

\section{Soil sampling:-}

The representative soil samples were taken from the two soils before addition of any treatments and after harvesting of wheat to determine soilavailable $\mathrm{N}, \mathrm{P}$ and $\mathrm{K}$ (mg kg soil- ${ }^{-1}$ ) and organic matter \% as mentioned by (Hesse, 1971).

All data were statistically analyzed according to the technique of analysis of variance (ANOVA) and the least significant differences between the treatment means were compared as published by Gomez and Gomez (1984).

\section{RESULTS AND DISCUSSION}

\section{Fresh, dry shoot and chemical composition:-}

Data in Table 3 reveal that fresh, dry weights $\left(\mathrm{g} \mathrm{pot}^{-1}\right)$ and nutrients uptake $\left(\mathrm{mg} \mathrm{pot}^{-1}\right)$ of wheat plant as affected by the application of rice straw (RS), rice straw RS with farmyard manure FYM) mixture and $\mathrm{N}$-fertilizer rates in two alluvial soils during 2005/2006 season.

Table 3 clearly appears that the additional of rice and (rice + FYM) mixture and $\mathrm{N}$ fertilizer rates had an insignificant effect on fresh and dry weights $\left(\mathrm{g} \mathrm{pot}^{-1}\right)$ of wheat plant under studied soils.

Also, Table 3 reveal that the highest mean values of fresh and dry weights were ( 6.78 and $\left.3.44 \mathrm{~g} \mathrm{pot}^{-1}\right)$ at the soil collected from rice cultivation occurred with the treatment of $20 \mathrm{~m}^{3} \mathrm{fed}^{-1}$ of RS with FYM (W2) $+37.5 \mathrm{~kg} \mathrm{~N}$ $\mathrm{fed}^{-1}$ (N2 half nitrogen dose), respectively. Whereas, the lowest mean values of total fresh and dry weights were (4.45 and $\left.1.21 \mathrm{~g} \mathrm{pot}^{-1}\right)$ occurred with the untreated soil (control), respectively.

As shown in the same Table, data reveal that mean values of $N, P$ and K-uptake $\left(\mathrm{mg} \mathrm{pot}^{-1}\right)$ by shoot of wheat plants was increased significantly with added organic wastes rates W0 (control), W1(RS) and W2 (RS + FYM), and $\mathrm{N}$ rates; N0 (control), N1(all dose) and N2 (half dose) at two alluvial soils. The increase in dry weight per plant due to nitrogen fertilization may be attributed to the role of nitrogen in encouraging cell elongation, cell division and consequently increasing vegetative growth and activation of photosynthesis process and metabolic which reflected increases in dry weight, EL-Zehery (2003).

Regarding the effect of rice straw (RS), rice straw RS with farmyard manure $\mathrm{FYM}$ ) and $\mathrm{N}$ fertilizer rates on absorbed $\mathrm{N}$ and $\mathrm{K}$ nutrients, Data presented in Table 3 reveal that the maximum mean values of these characters were $\left(74.40\right.$ and $\left.69.4121 .35 \mathrm{~g} \mathrm{pot}^{-1}\right)$ produced from the application $20 \mathrm{~m}^{3} \mathrm{fed}^{-1}$ of (RS + FYM) mixture and half $\mathrm{N}$ dose $(37.50 \mathrm{~kg} \mathrm{~N}$ $\mathrm{fed}^{-1}$ ) at the collected soil from rice cultivation, respectively. While, the minimum mean values of $\mathrm{N}$ and $\mathrm{K}$ nutrients were $\left(14.79\right.$ and $\left.12.71 \mathrm{mg} \mathrm{pot}^{-1}\right)$ occurred with the untreated soil (control), respectively. 
On the other hand, the same Table shows that the highest means of $\mathrm{P}$ uptake by shoot were $\left(21.35 \mathrm{mg} \mathrm{pot}^{-1}\right)$ produced from the interaction of W2 ( $\mathrm{FYM}+$ rice straw) at a rate of $20 \mathrm{~m}^{3} \mathrm{fed}^{-1}$ and $37.50 \mathrm{~kg} \mathrm{~N}^{-1} \mathrm{fed}^{-1}$ (half $\mathrm{N}$ dose) of $\mathrm{N}$ fertilizer in the $1^{\text {st }}$ soil that collected from rice cultivation. Meanwhile, the lowest mean of the P-uptake were $\left(0.48 \mathrm{mg} \mathrm{pot}^{-1}\right)$ occurred with the check treatments (control). Noufal et al., (2005) found that all organic materials increased availability of N, P and, $\mathrm{K}$ in the soil as well as the dry matter yield of barley plants.

\section{Grains weight:-}

Data in Table 4 show the effect of rice straw (RS), rice straw RS with farmyard manure $\mathrm{FYM}$ and $\mathrm{N}$ fertilizer rates had a significant and an insignificant effect on grain weight $\left(\mathrm{g} \mathrm{pot}^{-1}\right)$ and weight of 100 grains $(\mathrm{g})$ during 2005/2006 season, respectively.

Table 4: Means of grain yield $\left(\mathrm{g} \mathrm{pot}^{-1}\right)$ and weight of 100 grains of wheat crop as affected by rice straw, FYM and $\mathrm{N}$ fertilizer rates after 2005/2006 season.

\begin{tabular}{|c|c|c|c|c|}
\hline \multicolumn{3}{|c|}{ Treatments } & $\begin{array}{l}\text { grains weight } \\
\left(\mathrm{g} \mathrm{pot}^{-1}\right)\end{array}$ & $\begin{array}{l}\text { Weight of } 100 \\
\text { grains }(\mathrm{g})\end{array}$ \\
\hline \multirow{12}{*}{ Rice } & \multirow{3}{*}{ W0 } & No & 3.45 & 4.80 \\
\hline & & N1 & 3.89 & 5.00 \\
\hline & & N2 & 4.03 & 4.92 \\
\hline & \multicolumn{2}{|c|}{ Means } & 3.79 & 4.91 \\
\hline & \multirow{3}{*}{ W1 } & No & 3.62 & 5.06 \\
\hline & & N1 & 4.10 & 5.32 \\
\hline & & N2 & 4.33 & 5.44 \\
\hline & \multicolumn{2}{|c|}{ Means } & 4.02 & 5.27 \\
\hline & \multirow{3}{*}{ W2 } & No & 3.77 & 5.18 \\
\hline & & N1 & 4.58 & 5.50 \\
\hline & & N2 & 5.04 & 5.63 \\
\hline & \multicolumn{2}{|c|}{ Means } & 4.46 & 5.44 \\
\hline \multicolumn{3}{|c|}{ Average } & 4.09 & 5.21 \\
\hline \multirow{11}{*}{ Cotton } & \multirow{3}{*}{ Wo } & N0 & 2.64 & 4.85 \\
\hline & & N1 & 3.48 & 4.96 \\
\hline & & N2 & 3.49 & 4.94 \\
\hline & \multicolumn{2}{|c|}{ Means } & 3.20 & 4.92 \\
\hline & \multirow{3}{*}{ W1 } & No & 2.95 & 5.31 \\
\hline & & N1 & 3.81 & 5.44 \\
\hline & & N2 & 4.22 & 5.53 \\
\hline & \multicolumn{2}{|c|}{ Means } & 3.66 & 5.43 \\
\hline & \multirow{3}{*}{ W2 } & No & 3.40 & 5.42 \\
\hline & & N1 & 4.09 & 5.65 \\
\hline & & N2 & 5.73 & 5.73 \\
\hline & \multicolumn{2}{|c|}{ Means } & 4.41 & 5.60 \\
\hline \multicolumn{3}{|c|}{ Average } & 3.76 & 5.32 \\
\hline \multicolumn{3}{|c|}{ LSD at 0.05} & 0.56 & NS \\
\hline
\end{tabular}


With respect to grains weight $\left(\mathrm{g} \mathrm{pot}^{-1}\right)$ of wheat plant, data in Table 4, reveal that, As well as, the plants treated with $20 \mathrm{~m}^{3} \mathrm{fed}^{-1}(\mathrm{FYM}+\mathrm{RS})$ mixture gave the highest mean values of fresh weight were (4.46 and $\left.4.41 \mathrm{~g} \mathrm{pot}^{-1}\right)$ at the $1^{\text {st }}$ and $2^{\text {nd }}$ soil, respectively. Whereas, the lowest mean values of this attribute were $\left(3.79\right.$ and $\left.3.20 \mathrm{~g} \mathrm{pot}^{-1}\right)$ at $1^{\text {st }}$ and $2^{\text {nd }}$ soil respectively, obtained from the untreated treatments (without organic application).

As shown in Table 4, the highest mean values of grains weight were (5.04 and $\left.5.73 \mathrm{~g} \mathrm{pot}^{-1}\right)$ at the $1^{\text {st }}$ and the $2^{\text {nd }}$ soil occurred for the treatment of $20 \mathrm{~m}^{3} \mathrm{fed}^{-1}$ of RS with FYM (W2) $+37.5 \mathrm{~kg} \mathrm{~N} \mathrm{fed}^{-1}$ (N2 half nitrogen dose). Whereas, the lowest mean values of grains weight were $\left(3.45\right.$ and $2.64 \mathrm{~g} \mathrm{pot}^{-}$ ${ }^{1}$ ) at the $1^{\text {st }}$ and $2^{\text {nd }}$ soil respectively occurred for the untreated soil (control). The obtained increases are due to the high content of organic matter in these organic residues Abdel Aal et al., (2003)

Regarding the effect of rice straw (RS) with farmyard manure (FYM) and $\mathrm{N}$ fertilizer rates on weight of 100 grains $(\mathrm{g})$, Table 4 reveals that weight of 100 wheat grains had a with addition of organic waste rates from 0 ( W0 ) up to $20 \mathrm{~m}^{3} \mathrm{fed}^{-1} \mathrm{RS}$ (W1) and RS + FYM (W2). The highest mean values of weight of 100 wheat grains were $(5.44$ and $5.60 \mathrm{~g})$ at the $1^{\text {st }}$ and $2^{\text {nd }}$ soil respectively, occurred with added a rate of $20 \mathrm{~m}^{3}$ fed. Moreover, the plots that received from $20 \mathrm{~m}^{3} \mathrm{fed}^{-1}$ of (RS + FYM) mixture (W2) at a rate of $37.50 \mathrm{~kg} \mathrm{~N}$ $\mathrm{fed}^{-1}$ (half dose; N2) achieved the highest weight of 100 wheat grains (5.63 and $\left.5.73 \mathrm{~g} \mathrm{pot}^{-1}\right)$ at the $1^{\text {st }}$ and $2^{\text {nd }}$ soil respectively. Meanwhile, the lowest values residual soil- $\mathrm{N}$ content were $(4.80$ and $4.85 \mathrm{~g})$ at the $1^{\text {st }}$ and $2^{\text {nd }}$ soil respectively, produced from untreated plots (control).

\section{3. $\mathrm{N}, \mathrm{P}$ and $\mathrm{K}$ uptake by grains of wheat crop:-}

Table 5 shows that the mean values of $\mathrm{N}, \mathrm{P}$ and $\mathrm{K}$ uptake $\left(\mathrm{g} \mathrm{pot}^{-1}\right)$ by wheat grains were significantly affected with the additional of rice, (rice + FYM) mixture and $\mathrm{N}$ fertilizer rates under both of the studied soils during a season 2005/2006.

Data presented in Table 5 reveal that the highest mean values of $\mathrm{N}$ uptake was $\left(86.10 \mathrm{~g} \mathrm{pot}^{-1}\right)$ at $2^{\text {nd }}$ soil collected from cotton cultivation produced from the additional of W2 (FYM + rice straw) mixture at a rate of $20 \mathrm{~m}^{3} \mathrm{fed}^{-1}$ and $\mathrm{N}$ fertilizer at a rate of $37.50 \mathrm{~kg} \mathrm{~N}^{-1}$ (half $\mathrm{N}$ dose). While, the lowest values were $\left(18.82 \mathrm{~g} \mathrm{pot}^{-1}\right)$ produced from the untreated treatment (control).

In the contrary, the same Table refers that the highest mean values of $\mathrm{P}$ and $\mathrm{K}$ uptake were (15.26 and $\left.27.95 \mathrm{~g} \mathrm{pot}^{-1}\right)$ at the $1^{\text {st }}$ soil collected from the rice cultivation, respectively, obtained from added (RS + FYM) mixture at a rate of $20 \mathrm{~m}^{3} \mathrm{fed}^{-1}$ (W2) with $\mathrm{N}$ fertilizer at a rate of $37.5 \mathrm{~kg} \mathrm{~N}^{-1}$ fed (half dose N2). Meanwhile, the lowest mean value of $P$ and $K$ uptake were (5.45 and $4.65 \mathrm{~g} \mathrm{pot}^{-1}$ ) at the $1^{\text {st }}$ soil, respectively occurred without addition of previous treatment (control). 
Table 5: Means of $\mathrm{N}, \mathrm{P}$, and $\mathrm{K}$ uptake $\left(\mathrm{g} \mathrm{pot}^{-1}\right)$ by grains of wheat crop as affected by rice straw, $F Y M$ and $N$ fertilizer rates after 2005/2006 season.

\begin{tabular}{|c|c|c|c|c|c|}
\hline \multirow{2}{*}{\multicolumn{3}{|c|}{ Treatments }} & \multicolumn{3}{|c|}{ Nutrients uptake $\left(\mathrm{g} \mathrm{pot}^{-1}\right)$} \\
\hline & & & $\mathbf{N}$ & $\mathbf{P}$ & $\mathrm{K}$ \\
\hline \multirow{11}{*}{ Rice } & \multirow{3}{*}{ Wo } & No & 18.22 & 5.45 & 4.65 \\
\hline & & N1 & 37.70 & 6.21 & 6.42 \\
\hline & & N2 & 40.30 & 6.50 & 6.73 \\
\hline & \multicolumn{2}{|c|}{ Means } & 32.07 & 6.05 & 5.93 \\
\hline & \multirow{3}{*}{ W1 } & No & 20.90 & 5.89 & 12.18 \\
\hline & & N1 & 44.20 & 12.06 & 17.06 \\
\hline & & N2 & 45.90 & 12.88 & 17.51 \\
\hline & \multicolumn{2}{|c|}{ Means } & 37.00 & 10.28 & 15.58 \\
\hline & \multirow{3}{*}{ W2 } & No & 22.31 & 5.99 & 12.56 \\
\hline & & N1 & 57.25 & 14.61 & 27.86 \\
\hline & & N2 & 66.40 & 15.26 & 27.95 \\
\hline & \multicolumn{2}{|c|}{ Means } & 48.65 & 11.95 & 22.79 \\
\hline \multicolumn{3}{|c|}{ Average } & 39.24 & 9.43 & 14.77 \\
\hline \multirow{12}{*}{ Cotton } & \multirow{3}{*}{ Wo } & No & 15.93 & 5.19 & 11.19 \\
\hline & & N1 & 35.11 & 6.57 & 18.25 \\
\hline & & N2 & 46.25 & 6.97 & 18.90 \\
\hline & \multicolumn{2}{|c|}{ Means } & 32.43 & 6.24 & 16.11 \\
\hline & \multirow{3}{*}{ W1 } & No & 39.45 & 5.78 & 11.78 \\
\hline & & N1 & 64.90 & 7.12 & 19.45 \\
\hline & & N2 & 66.80 & 8.79 & 20.15 \\
\hline & \multicolumn{2}{|c|}{ Means } & 57.05 & 7.23 & 17.13 \\
\hline & \multirow{3}{*}{ W2 } & No & 31.30 & 6.11 & 12.62 \\
\hline & & N1 & 76.33 & 14.22 & 23.31 \\
\hline & & N2 & 86.10 & 15.20 & 25.99 \\
\hline & \multicolumn{2}{|c|}{ Means } & 64.58 & 11.84 & 20.64 \\
\hline \multicolumn{3}{|c|}{ Average } & 51.35 & 8.44 & 17.96 \\
\hline \multicolumn{3}{|c|}{ LSD at 0.05} & 8.59 & 3.00 & 5.69 \\
\hline
\end{tabular}

\section{Soil fertilty:-}

The results in Table 6 show the effect of rice straw individually or combined of $\mathrm{FYM}$ and $\mathrm{N}$ fertilizer rates vigorously affected on $\mathrm{N}, \mathrm{P}$ and $\mathrm{N}$ contents (mg kg soil-1) during 2005/2006 season.

As shown in Table 6,the highest mean values of soil-N contents ( $\mathrm{mg} \mathrm{kg}$ soil-1) were (91.88 and $\left.142.19 \mathrm{mg} \mathrm{kg} \mathrm{soil}^{-1}\right)$ at the $1^{\text {st }}$ and $2^{\text {nd }}$ soil respectively, obtained from plots that received $37.5 \mathrm{~kg} \mathrm{~N}^{-1}$ (half dose) with the combined effect of added (RS + FYM) mixture at a rate of $20 \mathrm{~m}^{3} \mathrm{fed}^{-1}$. Meanwhile, the lowest mean values of residual $\mathrm{N}$ contents $\left(\mathrm{mg} \mathrm{kg} \mathrm{soil}^{-1}\right)$ were (65.62 and $52.50 \mathrm{mg} \mathrm{kg} \mathrm{soil}^{-1}$ ) at the $1^{\text {st }}$ and $2^{\text {nd }}$ soil respectively, produced from the untreated plots.

It is worthy to note that the additional of organic wastes may be improving soil physical and biological properties, which are reflected 
generally, on soil fertility status and thus the dynamic changes of $\left(\mathrm{NH}^{+}{ }_{4}+\mathrm{NO}\right.$ 3) $-\mathrm{N}$ in the upper $30 \mathrm{~cm}$ of soil could be influenced, to a great extent (LeeChangHoon et al., 2004).

Table 6 refers that the application of rice straw, FYM and $N$ rates individually or combination of them caused a pronounced effect on residual soil-P ( $\left.\mathrm{mg} \mathrm{kg} \mathrm{soil}^{-1}\right)$ at two alluvial soils. The highest mean value of residual soil-P were (111.15 and $\left.122.85 \mathrm{mg} \mathrm{kg} \mathrm{soil}^{-1}\right)$ at the $1^{\text {st }}$ and $2^{\text {nd }}$ soil, respectively, obtained from (RS + FYM) mixture at a rate of $20 \mathrm{~m}^{3} \mathrm{fed}^{-1}$ at a rate of $37.5 \mathrm{~kg} \mathrm{~N}$ fed $^{-1}$. Meanwhile, the lowest mean values of available soil- $P$ were $\left(58.50\right.$ and $\left.87.75 \mathrm{mg} \mathrm{kg} \mathrm{soil}{ }^{-1}\right)$ at the $1^{\text {st }}$ and $2^{\text {nd }}$ soil, respectively occurred with check treatments (control). The combined application of chemical fertilizers and compost could be an effective method to increase the plant availability of $P$ in soils by promoting microbial activity continuous fertilization increased the total and inorganic $P$ contents in plough layers. In NPK, inorganic $P$ fraction did not change with time, but organic $P$ content increased significantly. Moreover, long-term application of chemical fertilizer together with compost accelerated the decrease in the organic $P$ fraction. Increase in total, inorganic and extractable $\mathrm{P}$ with time may be closely related to the increase in the availability of accumulated $\mathrm{P}$ for rice growth (LeeChangHoon et al., 2004).

Table 6: Soil fertility as affected by rice straw, FYM and $\mathbf{N}$ fertilizer rates after wheat crop cultivation 2005/2006 season.

\begin{tabular}{|c|c|c|c|c|c|c|}
\hline \multicolumn{3}{|c|}{ Treatments } & $\begin{array}{c}\mathbf{N} \\
\left(\mathrm{mg} \mathrm{kg}^{-1}\right)\end{array}$ & $\begin{array}{c}\mathbf{P} \\
\left(\mathrm{mg} \mathrm{kg}^{-1}\right)\end{array}$ & $\begin{array}{c}\mathrm{K} \\
\left(\mathrm{mg} \mathrm{kg}^{-1}\right)\end{array}$ & $\begin{array}{c}\text { O.M. } \\
\%\end{array}$ \\
\hline \multirow{12}{*}{ Rice } & \multirow[t]{3}{*}{ W0 } & No & 65.62 & 58.50 & 156.20 & 2.22 \\
\hline & & N1 & 65.63 & 70.20 & 168.20 & 2.57 \\
\hline & & N2 & 65.63 & 70.20 & 168.20 & 2.87 \\
\hline & \multicolumn{2}{|c|}{ Means } & 65.63 & 66.30 & 164.20 & 2.55 \\
\hline & \multirow[t]{3}{*}{ W1 } & No & 80.94 & 76.05 & 174.00 & 2.87 \\
\hline & & N1 & 80.94 & 76.05 & 174.00 & 3.02 \\
\hline & & N2 & 85.31 & 81.90 & 185.60 & 3.18 \\
\hline & \multicolumn{2}{|c|}{ Means } & 82.40 & 78.00 & 177.87 & 3.02 \\
\hline & \multirow[t]{3}{*}{ W2 } & No & 85.31 & 81.90 & 208.80 & 3.33 \\
\hline & & N1 & 89.69 & 105.30 & 208.80 & 3.48 \\
\hline & & N2 & 91.88 & 111.15 & 220.00 & 3.48 \\
\hline & \multicolumn{2}{|c|}{ Means } & 88.96 & 99.45 & 212.53 & 3.43 \\
\hline \multicolumn{3}{|c|}{ Average } & 79.00 & 81.17 & 184.87 & 3.00 \\
\hline \multirow{12}{*}{ Cotton } & \multirow[t]{3}{*}{ W0 } & No & 52.50 & 87.75 & 150.80 & 1.82 \\
\hline & & N1 & 78.15 & 87.75 & 197.20 & 2.12 \\
\hline & & N2 & 98.44 & 96.52 & 243.60 & 2.12 \\
\hline & \multicolumn{2}{|c|}{ Means } & 76.36 & 90.67 & 197.20 & 2.02 \\
\hline & \multirow[t]{3}{*}{ W1 } & No & 98.44 & 96.52 & 261.00 & 2.42 \\
\hline & & N1 & 100.62 & 107.23 & 266.80 & 2.42 \\
\hline & & N2 & 131.25 & 108.22 & 272.60 & 3.21 \\
\hline & \multicolumn{2}{|c|}{ Means } & 110.10 & 103.99 & 266.80 & 2.68 \\
\hline & \multirow[t]{3}{*}{ W2 } & No & 133.44 & 108.22 & 278.40 & 3.33 \\
\hline & & N1 & 133.44 & 114.07 & 324.80 & 3.33 \\
\hline & & N2 & 142.19 & 122.85 & 336.40 & 3.48 \\
\hline & \multicolumn{2}{|c|}{ Means } & 136.36 & 115.05 & 313.20 & 3.38 \\
\hline \multicolumn{3}{|c|}{ Average } & 107.61 & 103.24 & 259.07 & 2.69 \\
\hline
\end{tabular}


As well as, Table 6 indicates that, the highest mean values of residual soil-K were $\left(212.53\right.$ and $\left.313.20 \mathrm{mg} \mathrm{kg} \mathrm{soil}{ }^{-1}\right)$ recorded in the $1^{\text {st }}$ and $2^{\text {nd }}$ soil, respectively occurred with presence of (RS + FYM) mixture at $20 \mathrm{~m}^{3} \mathrm{fed}^{-1}$. While, the lowest mean values of residual-K were $(164.20$ and $197.20 \mathrm{mg} \mathrm{kg}$ soil- $^{-1}$ ) produced the check treatment. Data listed in the Table 6 reveal that the maximum mean values of residual soil-K content were (220.00 and 336.40 $\left.\mathrm{mg} \mathrm{kg} \mathrm{soil}{ }^{-1}\right)$ achieved in the presence of $20 \mathrm{~m}^{3} \mathrm{fed}^{-1}$ (FYM + RS) mixture with $37.5 \mathrm{~kg} \mathrm{~N} \mathrm{fed}^{-1}$ (half $\mathrm{N}$ dose) at the $1^{\text {st }}$ and $2^{\text {nd }}$ soil, respectively. Meanwhile, the minimum mean values of residual soil-K content were (156.20 and 150.80 $\mathrm{mg} \mathrm{kg} \mathrm{soil}{ }^{-1}$ ) occurred at the $1^{\text {st }}$ and $2^{\text {nd }}$ soil, respectively occurred without addition of previous treatment (control). In general, it can be noticed that the contents of soil- $\mathrm{N}, \mathrm{P}$ and $\mathrm{K}\left(\mathrm{mg} \mathrm{kg} \mathrm{soil}{ }^{-1}\right.$ ) reached its maximum value under the combined effect of (FYM + RS) mixture at a rate of $37.5 \mathrm{~N} \mathrm{~kg} \mathrm{fed}^{-1}$ (half dose) in two alluvial soils. It might be attributed to the effect of several organic acids produced during organic matter decomposition which might have also increased nutrients availability.

Looking at the mean values of organic matter (\%), data illustrated in Table 6 reveal that application rate from 0 up to $20 \mathrm{~m}^{3}$ of rice straw or/and FYM markedly increased means of organic matter from (2.55 to 3.02 and $3.43 \%$ ) at the $1^{\text {st }}$ soil, as well as at the $2^{\text {nd }}$ soil means of organic matter were increased from (2.02 to 2.68 and $3.38 \%$ ) due to the same treatments previous, respectively.

After harvesting, data in Table 6 reveal also that the highest mean values of organic matter were (3.48 and $3.48 \%$ ) produced from $20 \mathrm{~m}^{3} \mathrm{fed}^{-1}$ rate of FYM + RS with $37.5 \mathrm{~N} \mathrm{~kg} \mathrm{fed}^{-1}$ at the $1^{\text {st }}$ and $2^{\text {nd }}$ soil, respectively. Meanwhile, the lowest mean values of organic matter were (2.22 and $1.82 \%)$ at the $1^{\text {st }}$ and $2^{\text {nd }}$ soil, respectively produced from the check treatment, respectively during the season of 2005/2006. It might be attributed to the effect of several organic acids produced during organic matter decomposition which might have also increased nutrients availability.

It could be concluded that application a rate of $20 \mathrm{~m}^{3} \mathrm{fed}^{-1}$ (RS + FYM) mixture and $37.5 \mathrm{~kg} \mathrm{~N}^{-1} \mathrm{fed}^{-1}$ (half dose) led to increasing the yield and nutrients uptake by wheat plants and then improving the soil fertility under alluvial soil conditions.

\section{REFERENCES}

Abdel-Aal, S. I.; Abdel-Hamid, S. A.; Ismail, A.; Abdel-Fatah and A. S.; Taalab (2003): Effect of organic farming practice on nutrient availability and wheat yield grown on Torripsmments. Egypt .J. Soil Sci.43:47-62.

Cottenie, A.; Verloo, M.; Kiekens, L.; Velghe, G., and Camerlynck, R. (1982). Chemical analysis of plant and soils Lab. Anal. Agroch. Fac. Agric. State University Gent., Belgium.

El-Zeky, M. M. (2005). Response of wheat to biofertilizer inoculation under different levels of inorganic nitrogen. J. Agric. Sci. Mansoura Dniv., 30(1): 701-710. 
El-Mancy, M. H. A. and E. M. Selim (2007). Productivity of wheat plants treated with some biological, organic and inorganic fertilizers. Egypt, J. Appl. Sci., (In Press).

El-Zehery, T. M. A. R. (2003): Dynamic of nutrients and reaction of fertilizers applied on the environment. Ph. D. Thesis. Fac. of Agric., Mansoura, Univ., Egypt.

FlieBbach, A.; H. R.; Oberholzer L. Gunst and P.; Mader (2006): Soil organic matter and biological soil quality indicators after 21 year of organic and Conventional farming. Agric., Ecosystems and Environment 118, 273284.

Gomez, K. A. and A. A. Gomez (1984). Statistical Procedures for Agriculture Research. Jhon Willy and Sons Inc. New York.

Hammad, S. A. (1996). Status and behavior of nitrogen in soils under different conditions. A review. J. Agric. Sci. Mansoura Univ., 21 (4):1559-1587.

Hesse, P. R. (1971). "A Text Book of Soil Chemical Analysis". John Murry (publishers) Ltd, 50 Albermarle Street, London.

Jackson, M. L. (1967). Soil Chemical Analysis. Printice- Hall of India, New Delhi.

Noufal, E. H. A.; F. M. Habib; M. G. Khalil and M. S. S. Abd El-Hai (2005): Effect of natural organic conditioners addition on some properties of calcareous soil. Its available content of some nutrents and their uptake by barley plant grown thereon. II- Effect on contents of available N, P and $\mathrm{K}$ barley growth and nutrients uptake. Egypt J. Agric. Res., 2 (2): 491-509.

Shehata, S.A.; A.G. Behairy and Z.F. Fawzy (2004). Effect of some organic manures on growth and chemical composition of sweet pepper growth in a sandy soil. Egypt. J. Agric. Res., 82(2): 5771.

Sheng Mao, Y.; L. Feng Min; G. Tian-Wen; W. Jian Guo; S. Bing Ling and J. Shao Ling (2006): Effect of long term fertilization on soil productivity and nitrate accumulation in Gansu Oasis. Agricultural Science in China. 5(1): 57-67.

Soliman, M. S. M.; A. A. Abdel-Aziz and R. A. Drar: (2001): Effect of nitrogen level, farmyard manuring and biofetilization on growth, yield and yield cowmponents of maize (Zea mays L.) Egypt, J. Apple. Sci.; 16:1511667

Tisdale, S. L., W. L. Nelson and I. D. Beaton. (2002). Soil fertility and fertilizers. 4th Ed. Macmillan Publishing Company, A division of Macmillan, Inc., New York, 754 pp.

Wang, K. R, Liu X. Zhou, W. J, Xie; X.L, Buresh, R. J. (2004): Effect of nutrient Recycling on soil fertility and sustainable Rice production. Journal of Agro Environment Science, 23, 1041-1045. (in Chinese).

Xu, Y. C. and Q. R. Shen (2004): Influence of long term combined application of manure and chemical fertilizer on supplying characteristics of nitrogen in soil and soil particle fractions. Acta Pedologica Sinica (in Chinese). 41(1): 87-92. 


\section{أثرإضـافة قش الأرز والسـماد البلدي ومعدلات التسـيد النتروجينـي على محصول القمح وخصوبة التربة التربة

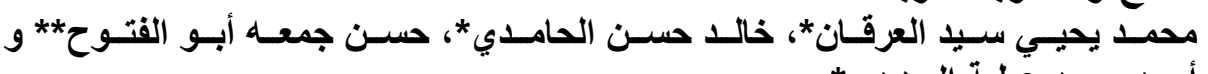

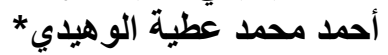

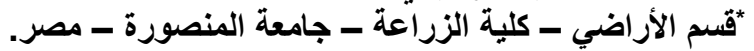

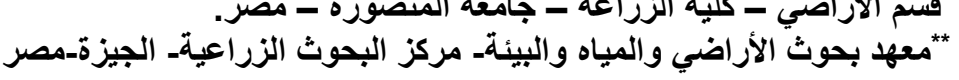

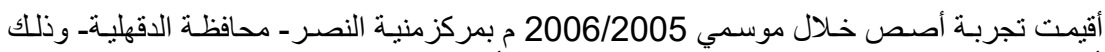

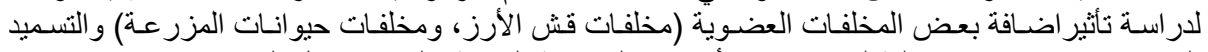

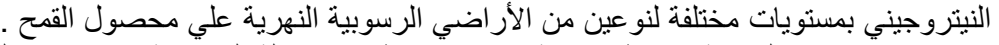

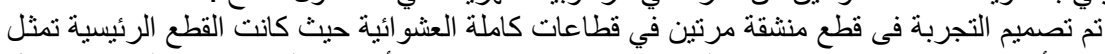

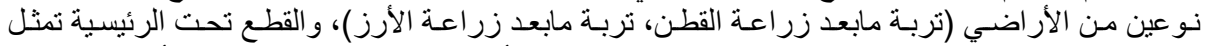

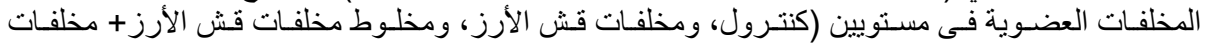

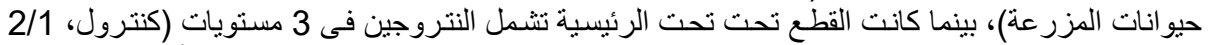

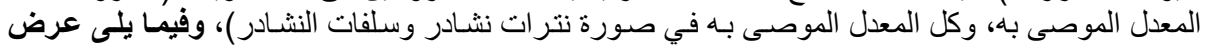

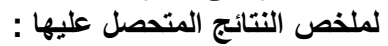

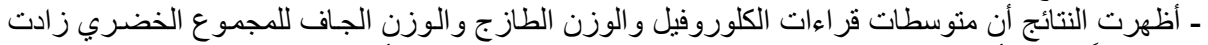

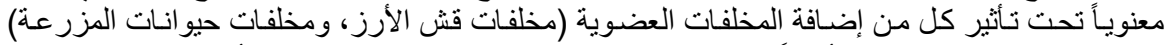

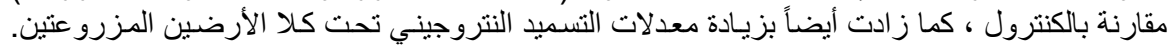

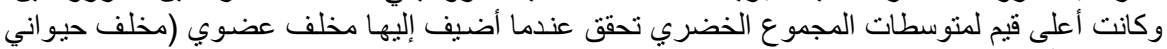

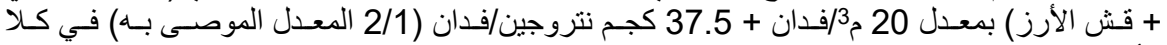

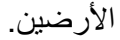

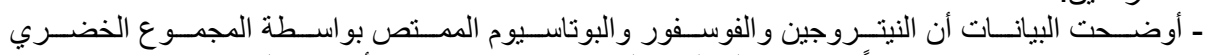

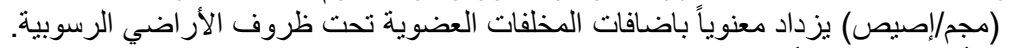

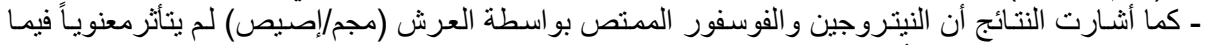

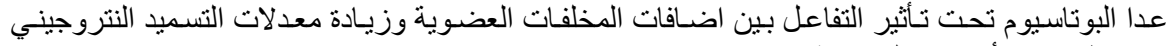

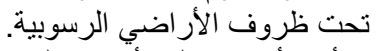

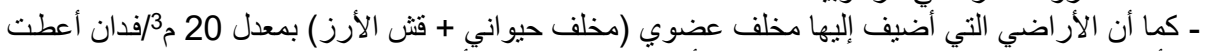

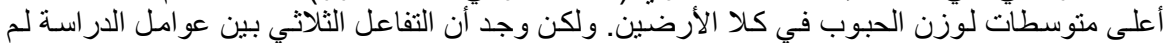

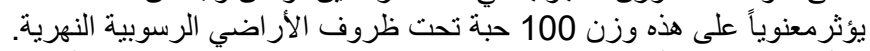

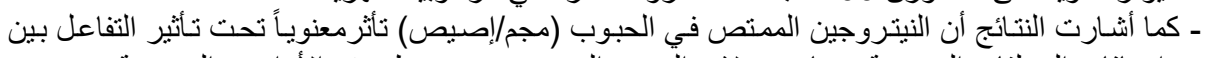

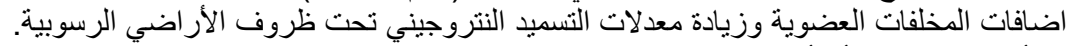

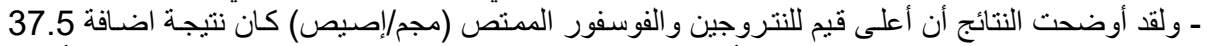

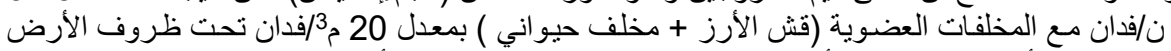

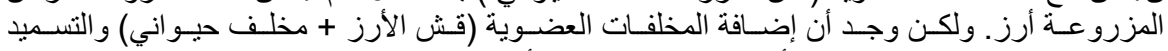

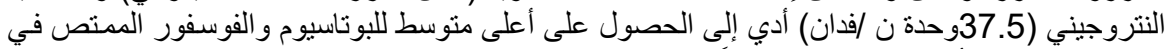

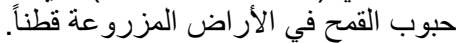

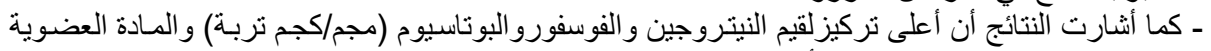

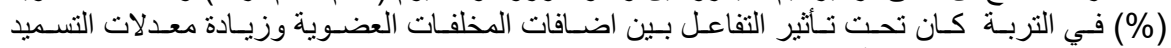
النتروجيني تحت ظروف التربة الأراضي الرسوبية. 
El-Arqan, M. Y. et al.

2471

2472

2473

2474

2475

2476

2477

2478

2479

2480

2481

2482 